Portland State University

PDXScholar

$1-1-2011$

\title{
The Effect of Role Models on the Attitudes and Career Choices of Female Students Enrolled in High School Science
}

Stephanie Justine Van Raden

Portland State University

Follow this and additional works at: https://pdxscholar.library.pdx.edu/open_access_etds Let us know how access to this document benefits you.

Recommended Citation

Van Raden, Stephanie Justine, "The Effect of Role Models on the Attitudes and Career Choices of Female Students Enrolled in High School Science" (2011). Dissertations and Theses. Paper 370.

https://doi.org/10.15760/etd.370

This Thesis is brought to you for free and open access. It has been accepted for inclusion in Dissertations and Theses by an authorized administrator of PDXScholar. Please contact us if we can make this document more accessible: pdxscholar@pdx.edu. 
The Effect of Role Models on the Attitudes and Career Choices of Female Students

Enrolled in High School Science

by

Stephanie Justine Van Raden

A thesis submitted in partial fulfillment of the requirements for the degree of

Master of Science in Teaching

in

General Science

Thesis Committee:

Michael Flower, Chair

Liza Finkel

Melissa Potter

Portland State University

(C)2011 
Girls who have high aptitude in math are not entering careers related to science, technology, engineering, and math (STEM fields) at the same rate as boys. As a result, female students may have fewer employment opportunities. This study explores one potential way to reduce the gap between male and female career aspirations and choices. Specifically, it looks at the impact of bringing women with careers in math- and sciencerelated fields into high school classrooms as role models. The study uses surveys to measure pre- and post-visit perceptions of science and scientific work as well as student's short-term interest in math and science courses. In addition to these surveys, student comments were collected about the role model visits. While the overall study yielded little statistical significance, it also indicated that the role model visits had some impact on student perceptions and choices and raised questions that warrant further 
TABLE OF CONTENTS

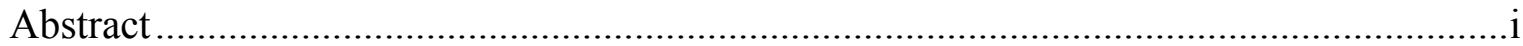

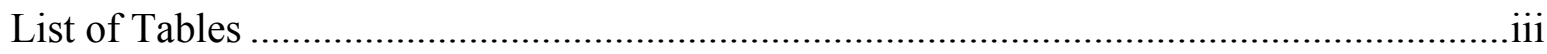

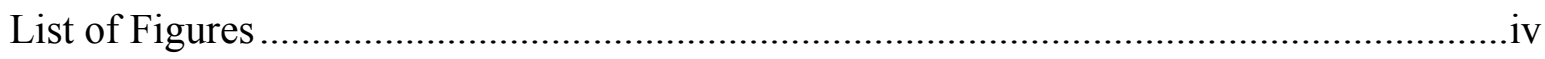

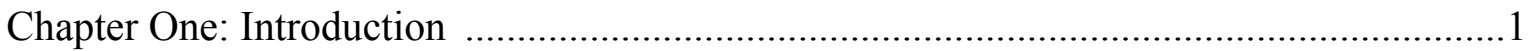

Chapter Two: Literature Review .........................................................................

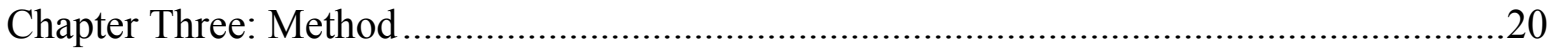

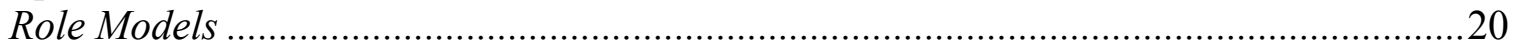

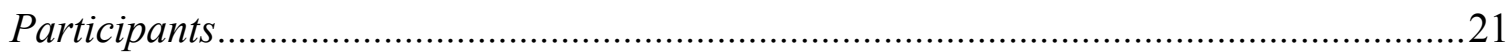

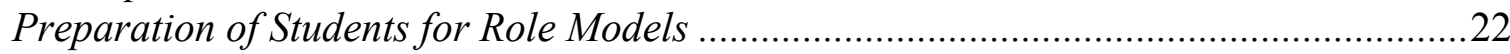

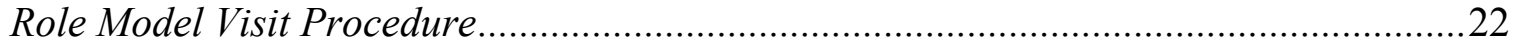

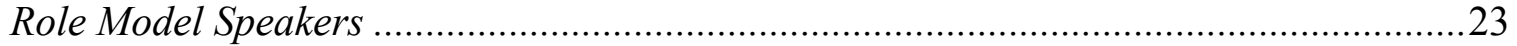

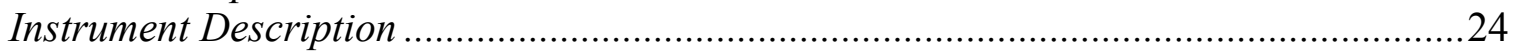

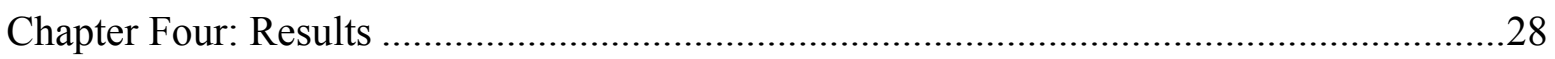

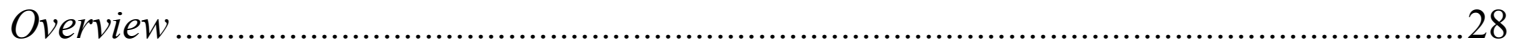

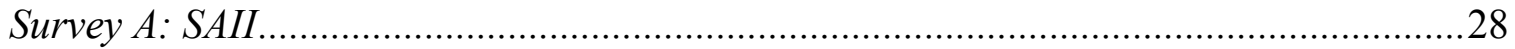

Analysis of individual student scores …………………....................................28

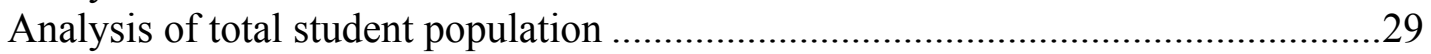

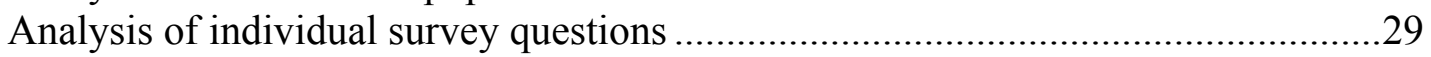

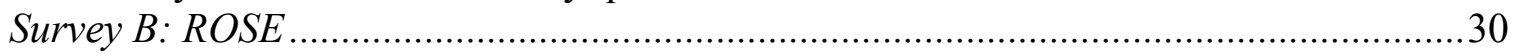

Analysis of total population of ROSE questionnaire participants ..............................31

Analysis of individual ROSE survey questions .......................................................32

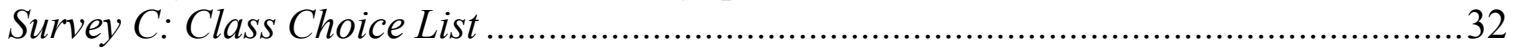

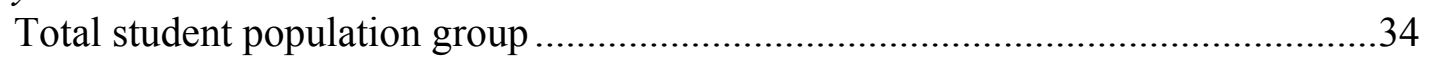

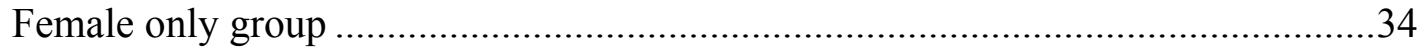

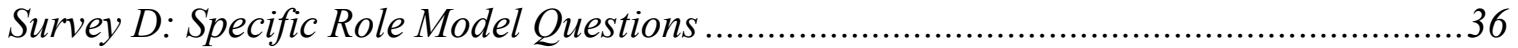

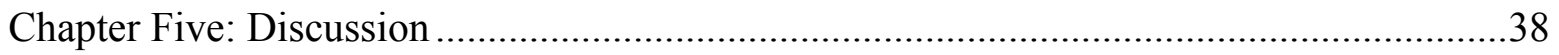

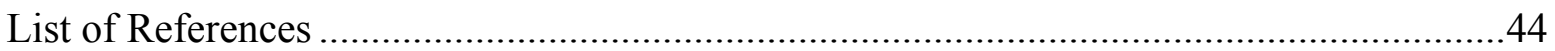

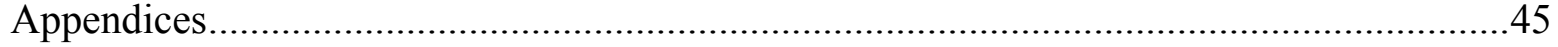

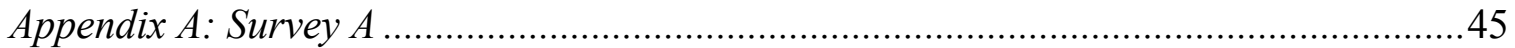

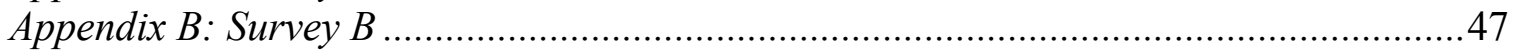

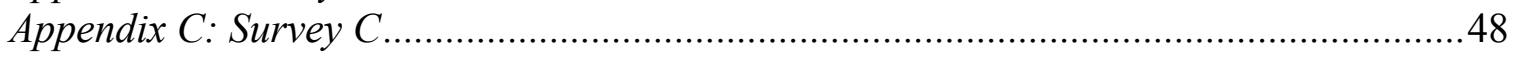

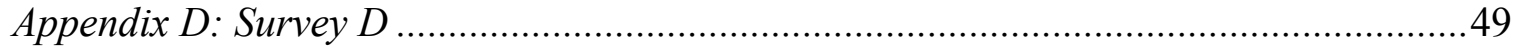

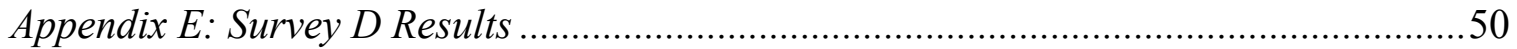

Appendix F: Human Subjects Review Letter ..........................................................51 


\section{LIST OF TABLES}

Table 1NAEP Results for $12^{\text {th }}$ grade students in science for 2005 ........................................... 1

Table 2 Studies Included in Literature Review and Organization .......................................... 7

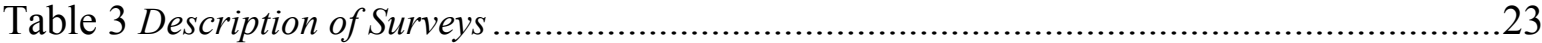

Table 4.1 Individual Student T-test Results for SAII Survey ..................................................27

Table 4.2 Questions with a Significant Difference in SAII Survey ..........................................28

Table 4.3 Significant Individual Student T-test Results for ROSE survey ..................................29

Table 4.4 Statements Evaluated for Change from the ROSE Questionnaire ...............................30

Table 4.5 Class Choice List Categories and T-test Results ...................................................31 


\section{LIST OF FIGURES}

Figure 4.1 T-test Scores for Individual Questions in the SAII survey .................................28

Figure 4.2 All Courses All Student Pre vs. Post visit survey ...............................................32

Figure 4.3 Female All Courses Choices Pre verses Post Visit Survey .................................33

Figure 4.4 Female Student Math-Prerequisite Science Courses Pre to Post Visit Survey....34 
Introduction

The aptitude for girls and boys in science is approximately the same. (Burkam, Lee, and Smerdon, 1997) Girls perform better in some areas of science and boys perform better in other areas of science, but the differences are not dramatic. This is evident when looking at the National Assessment of Educational Progress (NAEP) scores (2000 and 2005). There is no significant difference between male and female science achievement scores for 4th, 8th, and 12 th grades. When taking a closer look at 12 th graders, it was found that both male and female students had the same scores for life science. Males were ahead of females in both physical and earth science, though the difference was negligible (Table 1). Similarly, Burkam, Lee and Smerdon (1997), who tested $8^{\text {th }}$ grade and $10^{\text {th }}$ grade students, demonstrated a slight, but not significant, achievement gap between female and male students in both life and physical science achievement tests.

\begin{tabular}{|c|c|c|c|}
\hline \multicolumn{4}{|l|}{ Table 1} \\
\hline \multicolumn{4}{|c|}{ NAEP Results for $12^{\text {th }}$ grade students in science for 2005} \\
\hline Science Section from Test & Boys & Girls & Difference \\
\hline Life Science & 148 & 148 & 0 \\
\hline Physical Science & 151 & 145 & 6 \\
\hline Earth and Space Science & 148 & 143 & 5 \\
\hline
\end{tabular}

Even when female students have the math skills needed to major in science in college, they are more likely to choose a non-science course of study. This is evident 
when looking more closely at studies done by Klawe and Leverson (1995), Meyer

(1998), as well as Ceci, Williams, and Barnett (2009). Klawe and Leverson (1995)

followed 2,000 high school graduates in Michigan. Those who had math scores to qualify for science majors were the primary subjects of the study. It was found that $50 \%$ of male students and $16 \%$ of female students who had qualifying math scores declared themselves as science majors. This is disquieting information as both groups of male and female students were highly qualified to do well in a science major. Additionally, Meyer (1998) found that females who had both high verbal and math scores on SATs were less likely than male students to pursue a science major in their higher education career. Likewise, Ceci, Williams, and Barnett (2009) found that females who had both high math and verbal scores were still more likely to not enter a math intensive field, such as, education or health, than male students with the same abilities. Each of these studies describes a startling trend. It would appear that female students are opting out of science majors at greater rates than males, but not as the result of an absence of ability.

Interests, choices, and aspirations differ significantly along gender lines. According to the National Assessment of Educational Progress, 55\% of male 12th grade students like science, compared to only $46 \%$ of females (NAEP, 2005). Additionally, $45 \%$ of male 12 th grade students think they are good at science, while only $34 \%$ of females are confident in science (NCES, 2005). These findings illustrate that although female students may have the aptitude to do well in science classes, they do not demonstrate interest in them as much as other fields of study (Klawe and Leverson, 1995). Eccles (1994) found that choices of major and career are greatly influenced by social agents in each student's life. Female students tend to place more value on 
socialization, family, and the arts. Female students tend to weigh their courses against these other factors. Whereas male students' sense of self isn't always threatened by succeeding in school, female students sometimes experience internal conflict about demonstrating their academic skills. Eccles (1994) looked at some questions these students might ask themselves: Will I be discriminated against? Do I feel I can succeed in this class? Will this class cost too much time to invest in other things I find important? Students take many things into consideration when they choose classes and make decisions about what career to pursue.

There are social and economic costs when women avoid pursuing the sciences and there are important reasons to develop, strengthen, and maintain female participation in the sciences. The greater the variety of individuals who enter careers in science, the greater the ability of the collective whole to solve problems, make discoveries, and generally gain from one another. Without the added benefit of female scientists, society will lose the contributions of unique individuals. Historically, female scientists such as Marie Curie, Rachel Carson and many others have made important contributions. Without these women, science would be lacking major advances. In fact there has been little or no change in the percentage of women entering into science and math careers between 1982-2000 (Taylor, 2001). This is significant in light of the immense changes in the job market over the past decade. Careers in computer science and engineering are increasing exponentially as the world is becoming more technology driven (Ceci, Williams, and Barnett, 2009). Consequently, girls who opt out of science related majors would have even fewer options in the future. Avoiding engineering, math, and science careers also has economic implications for women since these fields tend to be higher 
paying than the fields women traditionally enter. Women are paid on average 74 cents on the dollar compared with men (Nelson, 2001). This equates to a difference of $\$ 523,000$ in a lifetime. Without realizing it, females may be choosing careers that will on average pay less than they could make in a science-related field.

Burkam, Lee and Smerdon (1997) found factors that deter female students include the perceived relevance of course material to their lives, availability of the courses offered at their schools, and the quantity of hands-on activities in the classroom. They also report that both male and female high school students perceive scientists as loners who work in laboratories for long hours on abstract problems. According to these authors, stereotype seems to impact female students more than males, who do not tend to view this as a great deterrent. Female students regarded the perceived isolation of scientists as a deterrent due to a lack of social and family focus. If a female student believes that science is aggressive, unfeminine, theoretical, and done by loners, it is less likely that she will choose a career in science or related fields. A primary question, then is whether it is possible to increase the numbers of girls choosing STEM-related fields of study and work and if so, how. A review of the research on girls in science suggests that the following classroom activities could increase girls' interest, choice, and aspiration for careers in science fields.

1. Equitable Teaching Strategies give all students a level playing field._(Gurer and Camp, 2001)

2. Inquiry Learning can help students create their own knowledge through teacher-facilitated activities. It also allows students to explore personal interests and questions in science doing their own research. (Taylor, 2001) 
3. Cooperative groups are beneficial for female students. They allow students 5 to work together and avoid a feeling of competitiveness among their peers. (Taylor, 2001)

4. Having single sex classrooms greatly improves active engagement for females. It also allows for less distractions and competitiveness. (Gurer and Camp, 2001)

5. Self-Expressive Assignments can help students connect on a personal and applicable level to the material being covered. It also allows for peer/teacher assessment. (El-Sabban, 2008)

6. Role models can greatly help students connect with current scientists. Students gain access to professionals and develop new ideas regarding what that career requires and what they need to accomplish in order to pursue that career. (Eccles, 1993; Gurer and Camp, 2001)

Of this list of interventions, the one that interests me the most and which I study here is the influence of women role models. Bringing professional women scientists into the classroom can inform students about careers that they didn't know existed before. Students can get a real understanding of who a scientist or engineer is as a person, how they made their own career decision, and how they feel about their career. Furthermore, allowing someone other than the teacher to express their views in the classroom may produce a novel effect, resulting in students paying attention with greater interest. Perhaps the most important advantage is that bringing women role models into the classroom can demonstrate how women can find science-related careers to be both interesting and rewarding. My hypothesis is that bringing a professional scientist or 
engineer into the classroom for even one period can result in real perception changes, 6 inspiration, and a willingness to explore STEM fields - all for a very small cost in classroom time.

The study posed the question "in what ways does bringing female scientist role models into the classroom change female students' attitude and potential choice of high school science classes?" While it was not possible within the scope of this study to measure longitudinal data about the impact of the speaker visits on the students' college and career choices, I used questionnaires to measure pre- and post-visit attitudes about science and collected information about what math and science courses they want to take in high school. This study was conducted during 60-minute sessions on three Fridays over two months. The independent variable is the role models coming into the classroom. The dependent variable is survey response to the role models. These responses were measured with a pre- and post-visit surveys that included: an abbreviated version of the Scientific Attitude Inventory (SAII) (Moore and Foy, 1997); Section B of the Relevance of Science Education ROSE questionnaire (Sjøberg, 2004); a survey of high school science classes that students could use to indicate their interest level in science; and a response survey entitled, "Specific Role Model Questions." 


\section{CHAPTER TWO: LITERATURE REVIEW}

The literature on career choices describes a lack of females in math and math intensive sciences, posits reasons why female students are entering these careers in lower numbers than men, and suggests methods to increase female involvement. The following literature review includes three categories of research studies: descriptive studies of the difference in career choices of men and women, the needs of girls in science classroom settings, and teaching strategies aimed at helping female students gain access to science. By looking at these three topics, I can effectively describe the importance of trying new methods within high school classrooms to increase female student involvement in science.

\begin{tabular}{|c|c|}
\hline Topics & Pertinent Articles \\
\hline $\begin{array}{l}\text { Description of women entering } \\
\text { careers in science }\end{array}$ & $\begin{array}{l}\text { Ceci, Williams, and Barnett (2009) } \\
\text { Clawe and Leverson (1995) } \\
\text { Burkam, Lee and Smerdon (1997) }\end{array}$ \\
\hline $\begin{array}{l}\text { Female needs in a science classroom } \\
\text { setting }\end{array}$ & $\begin{array}{l}\text { Eccles (1994) } \\
\text { Nelson (2001) }\end{array}$ \\
\hline $\begin{array}{l}\text { Teaching Strategies to help female } \\
\text { students gain access to science }\end{array}$ & $\begin{array}{l}\text { Meyer (1998) } \\
\text { Taylor (2001) } \\
\text { El-Sabban (2008) } \\
\text { Gurer and Camp (2001) }\end{array}$ \\
\hline
\end{tabular}

The three studies describing women entering careers in science aim to give the reader a better understanding of why women are under-represented in math intensive science careers. Claw and Leverson (1995) point out an array of underlying reasons including environmental factors and self-perception as leading causes for the deficit of women in science. Burkan, Lee, and Smerdon (1997) found that female students have 
lower scores in physical science and choose fewer physical science classes in high school, which leads to a gender gap in physical sciences in high school and college courses. Female students perform lower on physical science standardized tests. Ceci, Wiliams, and Barnett (2009) agreed with both studies mentioned previously. It was concluded that the achievement gap was not the reason that women choose against a career in STEM fields. Females may choose not to pursue STEM fields based on sociocultural reasons including social pressure, family values, and desire to go into traditionally female careers.

Klawe and Leverson (1995) reviewed information concerning women entering computer science and computer engineering careers. Their purpose was to review current challenges women have in attaining career goals in both these areas and how their issues are being addressed. They found that both teachers and parents treat female and male students differently. A female student is less likely than a male student to have a personal computer at home and more likely to share a computer with siblings. One of the studies they cite looked at 2,000 high school students in Michigan and identified 280 males and 220 female students who had the math ability to pursue a career in science. It was found that $50 \%$ of the male students chose science as a career, however only $16 \%$ of the female students did. The researchers found that the women who graduated with a degree in science were less likely than men with a degree in science to go on to complete a doctorate. A study by Klawe (1995) found that there is a significant difference in selfesteem among the men and women who enter science-related careers. The men tend to consider themselves much more intelligent than the women. This was interesting when paired with the fact that women graduated with higher GPAs. It was also noted that the 
female students found the atmosphere in school contributed to this decrease in self-

esteem. The authors concluded that female students in science do not have less aptitude in science and math; rather the difficulties lie in the environment around them.

Burkam, Lee, and Smerdon (1997) used information gathered from the National Education Longitudinal Study that began in 1988. The subjects, 12,120 tenth grade students from the United States, were given a standardized, life and physical science test during their eighth and tenth grade years. In the eighth grade, the researchers found that although female students have a slight lead in performance over male students in life sciences, they are deficient in performance in the physical sciences. By the time they reached sophomore year the gap was maintained but did not widen. Physical science deficiencies were found in three areas: quantitative science, spatial-mathematical, and basic knowledge and reasoning. The gap in performance between boys and girls was greatest in quantitative science and negligible in basic knowledge and reasoning. This was even more evident when comparing high achieving female and male students. Burkam et al. focused mainly on why female students tend to gravitate toward life sciences. Female students wanted to apply science learning to their lives and for this reason life sciences were more attractive. The fact that higher science and math courses are most often electives rather than required means that fewer students overall are exposed to them.

Ceci, Williams, and Barnett (2009) focused on the socio-cultural reasons women are not equally represented in math intensive science careers. Ceci determined that this is not in fact due to biological differences, but rather due to a myriad of other reasons. This study used results from over 400 other studies from different fields of research. She 
found that female Ph.Ds, are much less likely to be selected for assistant professorship 10 positions than men. They are also twice as likely to leave science related careers than men. Female students are more likely to get better grades in math intensive courses in high school, excluding physics, where boys scored $1 \%$ better than girls. Both men and women receive equal grades in math courses in college. In high school, female Hispanic and Latin American students score higher in math than Hispanic and Latin American males. In generalized tests males were more likely to receive higher scores than females. Those females who did receive high math scores were more likely to receive equally high verbal scores. Females who have high scores in all areas allowed for greater choice of college majors. Ceci, et al. found that most female students declare majors that are typically associated with women, such as education and health, whereas male students dominate all STEM fields. Ceci concluded that socio-cultural factors and not biological factors contribute greatly to female underrepresentation in math intensive careers.

From the three studies described previously it is evident that female students may have a slight achievement gap in physical science, but the main reason they do not enter careers in math intensive science lies outside of their cognitive abilities. Female students rely on socio-cultural factors to influence their decision-making. They also tend to choose careers in life science, which are known to less about empirical data and more hands-on people oriented jobs.

Female students are influenced by both family values and cultural norms for femininity. This may change their attitude toward math and science regardless of their cognitive abilities. In a study of 1,000 students, Eccles (1993) found that female students are often more influenced by social values within the classroom than on finding an 
occupation that will provide money. Both female and male students identified

scientists as loners. Therefore many female students find being a scientist to be a poor choice. Nelson (2001) studied why female students who are gifted in math and science are still under-represented in STEM fields. He found that the reasons for this phenomenon could often be attributed to family involvement, maintaining a feminine appearance, peer pressure, and male-dominated classroom culture.

Eccles (1993) focused on a theoretical model that she and colleagues created to show the different social agents that can influence decision-making, particularly in female adolescent students. The model is a culmination of fifteen years of research. J. S. Eccles and her colleagues used 1,000 adolescents from southeastern Michigan as the study group. This model was used to discuss how female students could be influenced to make decisions to enter male-dominated occupations. Within this model Eccles shows the many factors that can influence decision-making. These included social agents, a person's gender role schema, short and long term goals, and the potential cost of the investment. Eccles found that females are less confident than males in science related fields. She looked at the value given to each subject and compared boys' choices to girls'. Boys were found to put high value in an occupation that would provide them with more money while girls were found to put high value on socialization, family, and the arts. Interestingly, both girls and boys identified scientists as loners who work in laboratories for long hours on abstract problems that have little to do with immediate social implications. Therefore, if someone values being social and focusing on family, it is unlikely they would want to be a stereotypical scientist. Eccles quotes a study by Lee Anne Bell to illustrate that female students tend to struggle to balance looking feminine, 
non-aggressive, and non-competitive with wanting to get good grades and do strong

work.

Nelson (2001) reported that although girls represented 50\% the gifted science students they are underrepresented in math science, and engineering occupations. These careers are shown to be higher paying than other careers and are dominated by males. Nelson found that three outside factors have been correlated with influencing gifted girls to choose involvement in gifted programs. These are peer pressure, family, and school environment. Peer pressure was the greatest deterrent to student success. Females were more likely to conform to low teacher expectations, shy away from opposite gender competition, and hide competence from peers. Family involvement helps to shape the girls' perception of male and female gifted students. Parents were less likely to see curiosity, abstraction, and problem solving skills in their female children than in their male children. Nelson also found that parent choice was the greatest influencer over the classes students choose to take. Lastly, school environment and its role in female involvement in gifted programs were considered. Nelson discussed that fact that students move from an integrated, holistic curriculum in elementary school to a compartmentalized, content-specific curriculum in secondary education. This transition tends to make science-related material less relevant and easy to integrate. For female students this tends to result in a loss of interest in STEM fields.

Finally, Nelson discussed the differences in the way teachers treated the gifted female students compared with the male students. Gifted male students were more often called on for problem solving and were given more attention than gifted females. Nelson completed the picture by describing what teachers can do to alleviate these problems. 
These included actively encouraging students to enroll in math and science courses, discussing stereotyping, maintaining equal teacher-student interactions, and encouraging all types of academic achievement.

Both Eccles and Nelson paint a picture of how female students approach class choices, classroom culture, and career choice. Female students rely heavily on family and peer input to choose classes and a career. When enrolled in science and math courses, gifted female students are treated differently then male students. There are lower expectations placed on the female student from family, teachers, and themselves to succeed within science and math courses.

The majority of teaching strategies recommended focus on connecting the content to the female student's life and keeping the classroom culture safe for all students. Taylor, Erwin, Ghose, and Perry-Thornton (2001) focused on several well-documented strategies to increase minority female involvement in science. The techniques which are well used in Oregon science classrooms included inquiry learning, cooperative groups, and equitable teaching strategies. Taylor et al also suggested mentoring. Mentoring in and of itself is often used in internships but rarely in a classroom setting. Meyer (1998) strongly suggested that the key to connecting a female student with science was a direct connection to their lives. El-Sabban (2008) also emphasized connecting students to the content in personal and artistic way through self-expression assignments. Lastly, Gurer and Camp (2001) gave a list of considerations when trying to help female students access science. Of considerable important was their suggestion to make female role models accessible to students in math and science. This method is used often in computer science, but was suggested as beneficial for many other careers. They found that in 
college and job situations junior-level women were much more likely to persist when 14 they had access to female professors or higher level role models.

Taylor, Erwin, Ghose, and Perry-Thornton (2001) highlighted recent research concerning how to create a teaching environment that will best cultivate female, and especially minority female, science students. The first strategy discussed focused on employing teachers who were highly qualified to teach their subject. The Third International Mathematics and Science Study (TIMSS) found that $41 \%$ of mathematics teachers got a degree in mathematics and only $16 \%$ of science teachers got a degree in science. Taylor also remarked that while the gap is closing between men and women in mathematics degrees it is widening in science. The group of women who do enter science careers include few from underrepresented minority groups. This is a problem for students of these groups who have the ability to excel in science. Taylor then focused on ways to increase minority female participation in science. Teaching strategies discussed included: equitable teaching strategies, inquiry learning, and cooperative groups. Cooperative groups were stressed heavily as a way to increase positive experiences for female students. Cooperative teaching that encourages students to express multiple viewpoints was also presented as a way to increase the success of minority female students. Taylor also introduced the idea of mentoring in the classroom as a way for minority students to connect with science.

Meyer (1998) reflects on her teaching and learning experiences, as well as those of others in order to describe what it means to be a female science and math student. She describes multiple examples of female students feeling out of place, discriminated against, and unfit to do well in science. She shows the readers what female students need 
in order to do well in science classes. Many students come into classroom with

problems of their own. Students want a holistic education. Meyer recommends hands-on inclusive approaches that connect the student to the content and gain new skills that they can continue to use. She focused on three main areas of empowerment: opening doors, inclusiveness, and the climate of the classroom. She gave multiple anecdotal glimpses of student learning in order to emphasize how to empower students in the classroom. She ends with a strong push to focus on connecting the student's life experiences to the content.

In a similar vein as Meyer (1998), El-Saban (2008) focuses on the need for students to connect on a personal and applicable level to the assignments given in a science classroom. El-Sabban (2008) used three classes at an all-women's college in Kuwait to implement a method of learning called self-expression assignment (SEA). Students in a required science class were assigned a paper and project of their choice. They were to research their chosen topic and implement a semester-long plan to complete their assignment. What made this class unique was the fact that the female students were encouraged to report their results in a wide variety of media, including art, in addition to submitted a written research write-up. The projects were displayed and fellow students and instructors were able to give constructive feedback and praise. Students were given strong support and guidance. The students were graded with a university-created rubric for both the speech and the paper. Volunteer faculty, as well as the teacher, graded the projects. The students who participated in this project were given an opinion survey that allowed comments. Of 119 who completed the project, 104 had a positive opinion. More than $90 \%$ of the students felt this assignment fit with the course, was beneficial to them, 
and helped them discover new things about science. Although this strategy worked well, it is time and material intensive. It also fits better with a more advanced student. More importantly, El-Sabban once again emphasized the female student's need to connect the material with life.

Compared to other researchers, who focused on specific teaching strategies, Gurer and Camp (2001) aligned teaching strategies to counteract the barriers that often inhibit females from entering careers in science. Gurer and Camp (2001) gathered information about women in computer science at a website of the Association for Computing Machinery-Committee on Women in Computing (ACM-W). From 1983-1998, there was a $28 \%$ decrease in women earning bachelor degrees in computer science. This trend continues through higher education and professors' positions. Only $8 \%$ of professors in computer sciences are female. This is disconcerting as females are entering college at a larger percentage each year. However, males are entering engineering and physical science as the majority, though both fields are gaining a larger percentage of female students each year. This is a problem for society because there are 346,000 unfilled IT positions in the United States as of 2000. This trend is expected to increase.

Of particular interest for this study is Gurer and Camp's discussion about the influence of role models with students. According to these authors, there are 14 major considerations that impact women's choices about participating in computer science. These include positive attitudes, computing experience, role models, all female environments, and equal access. The presence or absence of role models was heavily emphasized as either a deterrent or an incentive toward choosing science-related careers. Female students who had only male role models were much more likely to give up or 
avoid trying to enter science-related fields. According to the authors it is important for 17 females to have women classmates, teachers, and mentors in order for them to succeed in computer science. The authors then describes ways in which the ACM-W website helps educate about 14 major considerations were discussed at length, including ways that a teacher can combat each one to help their female students succeed in the computer sciences. Although this study focused primarily on careers in computer sciences, the strategies considered hold explanatory power for understanding why girls pursue STEM fields less frequently than boys and offer specific strategies for combating that phenomenon.

The literature surrounding female inclusion in science careers describes women as capable, motivated, and underrepresented. Women are choosing against careers in science as a result of social-cultural reasons. These choices can result from family, peer, and classroom interactions. Teachers need to realize that they cannot negate all the possible deterrents for their female students entering science careers. They can, however, use classroom-based techniques to promote equal ambition and motivation to pursue STEM careers. Some of these methods are inquiry learning, cooperative groups, selfexpression assignments, maintaining equal teacher-student interactions, discussing stereotyping, and integrating women role models into classes. Gurer and Camp's (2001) description of the use of role models as an effective method for helping female students succeed in sciences influenced my decision to study the impact of role modeling on female attitudes toward the sciences. 
CHAPTER THREE: METHODS

This is a mixed-method exploratory study of the effects of a particular teaching intervention on students in a secondary science classroom. The study posed the question "in what ways does bringing female scientist role models into the classroom change female students' attitude and potential choice of high school science classes?" The purpose of this study is to explore the impact that exposure to female scientist role models has on high school girls' perceptions of science and science careers and on their motivation to take science classes in the future. I also hope to contribute to the body of research on how best to increase the number of women in science and related careers.

\section{Role Models}

In order to determine the impact that exposure to successful women in science and engineering has on high school girls, I invited three career scientists to my Freshman Integrated Sciences classes April-May 2011. Each scientist's visit lasted half of one class period (45 minutes) and guest scientists were scheduled only once per week. The speakers were initially scheduled to come once a week for three consecutive weeks, but conditions arose preventing speakers from coming on consecutive weeks. Although there is no documented evidence that closely spaced visits impacts the outcome of this kind of presentation, I felt that spacing out the visits did dilute their power. All of the guest scientists were women with a current career in a STEM field, and were deemed appropriate speakers for a high school audience. The women were chosen first based on their career. The three speakers held jobs as a geotechnical engineer, a computer scientist/data network specialist, and a geologist and astrobiologist. Two of the speakers 
were chosen based on a recommendation from the Program Coordinator for the Oregon19 Pre-Engineering and Applied Sciences Initiative (OPAS), who had heard them speaking to high school classrooms. The third speaker was recommend by another teacher who had invited her to speak to her students several times. The speakers were asked to prepare for the visit by focusing on the following areas: how they became interested in their career, what they do on a daily basis, and the most interesting thing they have done in their career. All speakers were given a specific time frame in which to present and respond to questions from students. All speakers were also asked to talk about what they love about their job, what was difficult about getting to the place they are now in their career, and what their personal life is like.

\section{Participants}

The study was conducted with two different freshman integrated science classes of approximately 25 students each. Participation in the study was voluntary and a total of 24 students chose to participate. Eight of the participants were girls and sixteen were boys. Students in this study were 14-15 years olds and were enrolled in this class to receive science credit in high school. All of the students in both classes received the same treatment - exposure to role models.

The students who participated were students enrolled in those two classes located in what I will call "A” High School or AHS. This school has approximately 2,000 students. The population of AHS for 2009 was 58.2 percent White, 30.8 percent Hispanic, 7.6 percent Asian and 2.6 percent Black. Students with special needs at $11.94 \%$ followed by 
gifted students at $9.74 \%$ are the second largest subgroups. The ELL population is

$4.96 \%$. There are $30.2 \%$ of students who qualify for free or reduced lunch.

\section{Preparation of Students for Role Models}

Prior to meeting with the visiting female scientists, students learned about the scientists' careers. Students were asked to list questions to ask these scientists during a question-and-answer time following the guest scientist's presentation. These questions ranged from personal to professional questions about each scientist's life. Students were not limited to their prepared questions when the questions and answer times occurred.

\section{Role Model Visit Procedure}

1. During the first week of class students were given an informed consent form to take home. Both parent and student had to read and sign the form for the student to participate in this study. Students were given until the day before the first instrument was handed out to turn in the informed consent form.

2. The week preceding the first guest scientist, students were given all three pre-visit surveys. The directions for the different pre-visit surveys were explained to the class as a whole and to individual students when needed. These were collected immediately from each student.

3. The day before each scientist's visit, students were told the title, name, and career of the person coming. The job was explained in language the students could understand. Details of their careers were discussed. Students were asked to write down two questions 
they wanted answered by the scientist and turn them in. From this list I created a master list of questions to ask the scientist. Students were also encouraged to ask spontaneous questions during the guest scientist visit and there was never a lack of good questions.

6. The guest scientist was given 15-20 minutes to speak.

7. After the formal presentation was complete, students had 5-15 minutes to ask questions of the scientist. If 5 minutes had not passed and there were no more questions I began to ask questions from the master list I had compiled.

8. Before the end of class, students were asked to answer questions in Instrument D.

Steps 4-8 were repeated for each guest scientist.

Post-visit surveys were given after all guest scientists had completed their presentations.

\section{Role Model Speakers}

Speaker one works as a geotechnical engineer for the State Department of Transportation. She is the emergency repair go-to person. This speaker is in her early thirties and is single. During her presentation she described her job in great detail. She repairs washed out roads, cleans up after major floods, repairs sinkholes, and prepares for coming problems. She is also an engineer working on a regional River Bridge Project. During the presentation the speaker's demeanor was enthusiastic and confident. The speaker provided time for students to ask questions once the presentation had ended. Students were very interested to find out about this speaker's personal life and interests. 
Students asked about her religion, whether she likes chicken, plays a sport, has pets, 22 likes to travel, and other personal questions. Quite a few students also wanted to know more about sinkholes and how they occur. Information she described to students included: her religious beliefs, her love of Frisbee golf, travel, and her passion for engineering.

Speaker two manages a secure data storage facility in the urban area where the school is located. She has had many jobs, centering on a computer science background. She is completely self-taught with some credits toward a degree in sociology. She is in her mid-forties, single, and has three teenaged children. She gave us a narrative of her life choices. She has had a huge range of opportunities, most involving perks and travel. All of her jobs involved her having to prove her worth as a female around high-powered male individuals. The speaker's demeanor was passionate, humorous, and down-to-earth. Students had a lot of questions about how much money she makes, why she chose her career, and what kinds of perks she gets from her job. She told students about her $\$ 100,000$ paycheck, her free tickets to any concert or sporting event, the constant ability to change what she does in her career, and her passion for educating young men and women in IT careers.

Speaker three is a professor at a local university, works as an editor for a scientific journal, and writes grants to fund a mobile transition electron microscope (TEM) for high school classrooms. She is in her fifties, holds a Ph.D., has one child, and is married. This speaker talked about the intricacies of each job. She discussed life on other planets in some detail with students. As a class she has us look at pictures of bug eyes and pollen using a TEM. She also described the scientific writing process with students. After her 
presentation she answered questions. Most of their questions were about aliens.

Students were very interested in where we would find them, if we had found them, and what they would look like.

\section{Instrument Description}

This research project took the form of administering pre and post visit surveys in order to determine the impact of the female science role models on student attitudes toward choice of high school science classes, potential career paths, and general attitudes toward science as a field and as a form of employment. I administered three primary surveys as a packet before the first visit and after the third visit. These included: an abbreviated version of the Scientific Attitude Inventory (SAII) (Moore and Foy, 1997), Section B of the Relevance of Science Education ROSE questionnaire (Sjøberg, 2004), and a survey of high school science classes that students could use to indicate their interest level in science. Finally, I administered a response survey entitled, "Specific Role Model Questions" after the role model visits that asked open-ended questions about the participants' response to each speaker visit. Table Three provides a summary of all instruments used for this study.

\section{Table 3}

Description of Surveys

\begin{tabular}{|l|l|l|l|l|}
\hline Title & $\begin{array}{l}\text { Survey A: } \\
\text { Class Choice } \\
\text { List }\end{array}$ & $\begin{array}{l}\text { Survey B: } \\
\text { SAII }\end{array}$ & $\begin{array}{l}\text { Survey C: } \\
\text { ROSE part B only }\end{array}$ & $\begin{array}{l}\text { Survey D: } \\
\text { Specific Role } \\
\text { Model Questions }\end{array}$ \\
\hline Purpose & $\begin{array}{l}\text { To determine } \\
\text { immediate and } \\
\text { future class } \\
\text { choices. }\end{array}$ & $\begin{array}{l}\text { To determine the } \\
\text { students' beliefs } \\
\text { about the nature of } \\
\text { science as a field } \\
\text { and a career. }\end{array}$ & $\begin{array}{l}\text { To determine what } \\
\text { the student's } \\
\text { believe they want } \\
\text { to do as their future } \\
\text { career. }\end{array}$ & $\begin{array}{l}\text { To determine what } \\
\text { students think } \\
\text { about the role } \\
\text { models brought } \\
\text { into the classroom. }\end{array}$ \\
\hline
\end{tabular}




\begin{tabular}{|l|l|l|l|l|}
\hline Procedure & $\begin{array}{l}\text { This was given } \\
\text { twice, before and } \\
\text { after the } \\
\text { treatment. }\end{array}$ & $\begin{array}{l}\text { This was given } \\
\text { twice, before and } \\
\text { after the treatment. }\end{array}$ & $\begin{array}{l}\text { This was given } \\
\text { twice, before and } \\
\text { after the treatment. }\end{array}$ & $\begin{array}{l}\text { This was given } \\
\text { after each role } \\
\text { model visit. }\end{array}$ \\
\hline
\end{tabular}

The first survey, Survey A, was an abbreviated version of the Scientific Attitude Inventory (SAII), which was developed in 1972 by R.W. Moore and subsequently revised to eliminate gender bias. A copy of the questionnaire can be found in the Appendix A. The version I used consisted of thirty statements about science to which students responded on a Likert scale from A-E with A representing strong agreement and $\mathrm{E}$ representing strong disagreement. This survey is intended to determine students' "interest in science, their attitudes toward science, their views of scientists, and their desire to become scientists" (Assessment Tools in Informal Science, 1997). The SAII evaluates the strength or weakness of a student response to a given statement using a 5-point Likert scale. To convert the alphabetical scale used in the test to numeric data, I assigned the "A" the numerical value of 5 and the "E" a numerical value of 1 . For each student, I calculated the pre- and post-visit survey means separately and used this information to decide that a two-tailed t-test was the correct method of determining significance, as the population of means was nearly identical. I then created a table that allowed me to see the gender of the student and their t-test scores. Each student had an $\mathrm{N}$ of 30 for 30 questions total on the survey. Using these three types of analysis, I found few statistically significant increases in student interest in science and science-related careers.

The second survey, Survey B, was Section B of the Relevance of Science Education (ROSE) questionnaire entitled, "My Future Job," was used to determine 
students' interest in pursuing a career in science. The ROSE questionnaire consists of 25 twenty-six statements about general qualities and asks participants to rate whether they are "very important" or "not important" to them. The qualities or values listed are not specific to science, but my hope was to measure any changes in student scores as a result of the role model visits. In my analysis, I focused on items within the survey that related specifically to technical and environmental qualities. The ROSE questionnaire was used to evaluate qualities and relationships that students find attractive in their future career. Its purpose was to show whether there was a change in attitude among female and male students towards aspects of careers in science. The ROSE survey includes twenty-six questions, which ask students to rate "how important are the following issues for your potential future occupation or job?” Answers are given on a 4-point Likert scale from "very important" to "not important." I assigned "very important a numerical value of 4 and "not important" a numerical value of 1 . I then established the mean for the entire population across all questions and compared pre and post visit means. Then, I analyzed the individual statements within the ROSE questionnaire using a t-test to compare all student surveys as well to break out surveys by female students only. I then looked at individual student results.

The third survey, Survey C, was a class choice list that asked students to indicate which high school science classes they would be interested in taking. I was looking to see whether the role model visits impacted their selections on this survey. I divided science courses into four categories. The first is all courses together, including life sciences. This was the only category in which I included life sciences. The second category included math courses as well as science courses that require math prerequisites. The third 
category was the math-prerequisite science courses alone. The fourth category is specifically math courses. To compare pre and post visit surveys I assigned a 1 if the student chose a particular course and 0 if they didn't. I then added these numbers for each course to see if the number of students interested increased. For the analysis of Survey C, $\mathrm{n}$ was the number of classes being analyzed. The t-test described in each section were paired and two-tailed. The results were paired, as the data was a direct representation of each student's class choices before and after the speaker.

The final survey, "Specific Role Model Questions," asked three questions of students before and after each role model visit. These questions were: What was one thing you learned about the scientist's job? What was something that surprised you about the guest speaker? How did learning about this scientist impact you? I divided the answers to these four questions into four primary categories. These were: factual information about the speaker or her job; factual information about self; advice given by the speaker; and revelations by students. 


\section{CHAPTER FOUR: RESULTS}

\section{Overview}

The results section contains a description of all the data gathered during the study. The three surveys were used to answer the question, "in what ways does bringing female scientist role models into the classroom change female students' attitude and potential choice of high school science classes?" The SAII and the Class Choice Survey questionnaires were used to analyze changes in attitudes toward science classes. The ROSE survey asked about qualities in a job that are important to participants and the Specific Role Model questionnaire asked students to reflect on their experience with the speakers.

\section{Survey A: SAII}

Analysis of individual student scores

No student received a significant t-test score, however there were 4 female students who had a t-test result of 0.25 or lower, which means that there is $75 \%$ chance that there is a significant difference between the pre and post visit surveys. However, I needed $90 \%$ to establish true statistical significance. The t-test scores for individual students can be seen in Table 4.1. They are labeled by gender and ordered within gender by their T-test scores. 


\begin{tabular}{|l|l|l|l|}
\hline \multicolumn{5}{|l|}{ Table 4.1 } \\
Individual Student T-test Results for SAII Survey \\
\hline Gender & $\begin{array}{l}\text { T-test } \\
\text { Score }\end{array}$ & Gender & T-test Score \\
\hline $\mathrm{M}$ & 0.25 & $\mathrm{M}$ & 0.80 \\
\hline $\mathrm{M}$ & 0.27 & $\mathrm{M}$ & 0.81 \\
\hline $\mathrm{M}$ & 0.28 & $\mathrm{M}$ & 1.0 \\
\hline $\mathrm{M}$ & 0.37 & & \\
\hline $\mathrm{M}$ & 0.41 & $\mathrm{~F}$ & 0.15 \\
\hline $\mathrm{M}$ & 0.45 & $\mathrm{~F}$ & 0.17 \\
\hline $\mathrm{M}$ & 0.52 & $\mathrm{~F}$ & 0.24 \\
\hline $\mathrm{M}$ & 0.54 & $\mathrm{~F}$ & 0.24 \\
\hline $\mathrm{M}$ & 0.54 & $\mathrm{~F}$ & 0.58 \\
\hline $\mathrm{M}$ & 0.60 & $\mathrm{~F}$ & 0.60 \\
\hline $\mathrm{M}$ & 0.68 & $\mathrm{~F}$ & 0.71 \\
\hline $\mathrm{M}$ & 0.70 & $\mathrm{~F}$ & 0.99 \\
\hline $\mathrm{M}$ & 0.77 & $\mathrm{~F}$ & 1.0 \\
\hline Notes: No significant results are visible. \\
\hline \multicolumn{5}{|l}{} \\
\hline
\end{tabular}

Analysis of total student population

In looking at the pre and post visit means for the entire population of participants

I saw no significant increase. Knowing that there was no increase, I expected either a ttest that supported the null hypothesis or a t-test result that showed no difference. The result was 0.31 with an $\mathrm{N}$ of 750 , which indicates no statistical significance.

$\underline{\text { Analysis of individual survey questions }}$

For my analysis of individual SAII questions, I used a paired one-tailed t-test to compare pre and post survey results. I expected the data to show higher numbers representing an increase in student interest in science and science-related careers. I found no result above 0.5 on any individual question. The distribution of the results can be seen 


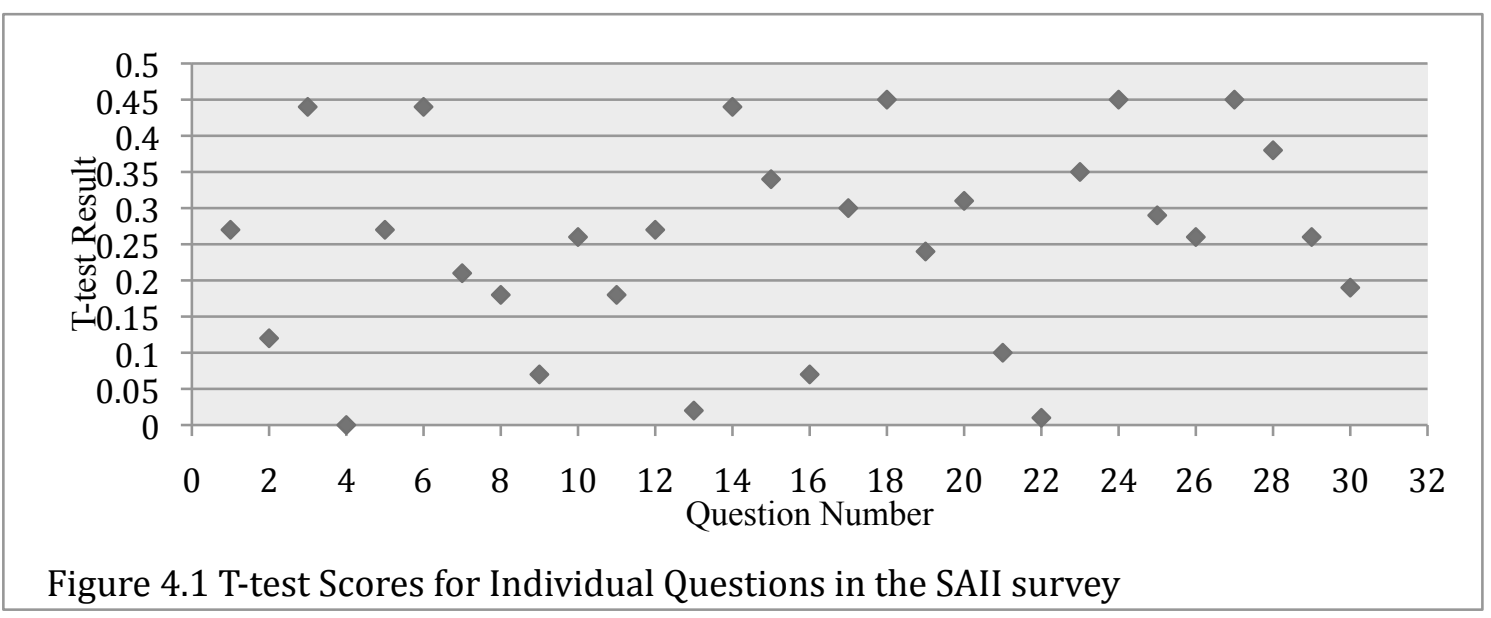

In fact, six questions showed statistical significance (2, 5, 6, 8, 23, and 27), having a t-test result of 0.1 or smaller. However, the trajectory of the change went against my hypothesis that role model visits would produce increased interest in science. The only exception was question 6 , whose change results supported my hypothesis. I will discuss potential reasons for these results in the discussion section.

\begin{tabular}{|l|l|l|l|}
\hline Table 4.2 \\
$\begin{array}{l}\text { Questions } \\
\text { Question } \\
\text { Number }\end{array}$ & Statement & $\begin{array}{l}\text { T-test } \\
\text { Score }\end{array}$ & $\begin{array}{l}\text { Increase or } \\
\text { Decrease* }\end{array}$ \\
\hline 2 & I would enjoy studying science. & 0.00 & Decrease \\
\hline 5 & Scientific ideas may be changed over time. & 0.05 & Decrease \\
\hline 6 & Scientists are always interested in better explanation of things. & 0.07 & Increase \\
\hline 8 & Working in a science laboratory would be fun. & 0.01 & Decrease \\
\hline 23 & People must understand science because it affects their lives. & 0.07 & Decrease \\
\hline 27 & Scientists do not have enough time for their families or for fun. & 0.10 & Decrease \\
\hline Note: $*$ from pre to post visit survey & & \\
\hline
\end{tabular}

\section{Survey B: ROSE questionnaire}

There was no statistical significance found either in the entire population or the individual questions from all students or the group of female students. When looking at 

among 10 students. Of these, eight were male and 2 were female. The results from seven male students and 1 female student supported my hypothesis and the results for 1 female and 1 male student went against my hypothesis. The T-test scores are listed in Table 4.3. I will elaborate on these findings in the discussion section.

\begin{tabular}{|l|l|l|}
\hline \multicolumn{3}{|l|}{ Table 4.3 } \\
Significant Individual Student & T-test Results for ROSE survey \\
\hline Gender & T-test Score & $\begin{array}{l}\text { Increase or Decrease from pre } \\
\text { to post visit survey }\end{array}$ \\
\hline Male & 0.001 & Increase \\
\hline Male & 0.002 & Decrease \\
\hline Male & 0.002 & Increase \\
\hline Male & 0.01 & Increase \\
\hline Male & 0.01 & Increase \\
\hline Female & 0.02 & Increase \\
\hline Male & 0.02 & Increase \\
\hline Male & 0.03 & Increase \\
\hline Female & 0.05 & Decrease \\
\hline Male & 0.09 & Increase \\
\hline
\end{tabular}

\section{Analysis of total population of ROSE questionnaire participants}

To begin I analyzed all the questions together to see if there was any statistical significance when using an $\mathrm{N}$ of 650 . The unpaired two-tailed t-test gave a result of 0.14 . Because my set $\mathrm{p}$ value needed to be below 0.05 , I found that the result of 0.14 was not significant. I also broke out the female students as a group to see if there were significance changes in pre and post visit surveys among female students. The unpaired two-tailed t-test value was 0.72 , meaning that there was no statistical significance. As a result of this analysis I began to look at individual questions. 
As mentioned previously, the questions on the ROSE questionnaire were not necessarily science-related, but some questions indicated qualities that tend to occur in science-related fields. For this reason, I chose to focus my analysis on questions 1, 7, 6, and 10, which indicate a preference for science-related qualities. The t-test results can be seen in Table 4.4. It is evident that there is no significant change from any of the four questions in the pre and post-visit surveys. Female student responses on statement 7 did change, but they were not deemed statistically significant because their probability wasn't low enough.

\begin{tabular}{|c|c|c|}
\hline \multicolumn{3}{|c|}{ Statements Evaluated for Change from the ROSE Questionnaire } \\
\hline Statements Ordered by Number on Survey & $\begin{array}{l}\text { All-Student } \\
\text { T-test Result }\end{array}$ & $\begin{array}{l}\text { Female Student } \\
\text { T-test Result }\end{array}$ \\
\hline 1. Working with people rather than things & 0.7 & 0.8 \\
\hline 6. Building or repairing objects using my hands & 1.0 & 1.0 \\
\hline 7. Working with machines or tools & 0.5 & 0.32 \\
\hline 10. Making, designing or inventing something & 1.0 & 1.0 \\
\hline
\end{tabular}

\section{Survey C: Class Choice List Survey}

The class list surveys asked students to indicate which high school science classes they would be interested in taking. I was looking for changes in the number of science classes students indicated they would be willing to take and for changes in the kind of science classes. The results were analyzed as two groups: total population and female students only. First, I will describe the results from the total population and then from the female only group. The comparison of pre and post visit surveys showed quite a few significant results both through descriptive and inferential statistics. The total population of participants showed an increase in the number of science classes they were interested 
in taking and specifically an increase in math-intensive science class such as physics, 32 engineering, and electronics.

Table 4.5

Class Choice List Categories and T-test Results

\begin{tabular}{|c|c|c|c|c|c|c|c|}
\hline \multicolumn{2}{|c|}{ All Courses } & \multicolumn{2}{|c|}{$\begin{array}{l}\text { Math \& Math- } \\
\text { Prerequisite Science } \\
\text { Courses }\end{array}$} & \multicolumn{2}{|c|}{$\begin{array}{l}\text { Math-Prerequisite } \\
\text { Science Courses }\end{array}$} & \multicolumn{2}{|c|}{ Math Courses } \\
\hline All & Female & All & Female & All & Female & All & Female \\
\hline $\begin{array}{l}\text { T-test: } \\
0.01\end{array}$ & $\begin{array}{l}\text { T-test: } \\
0.81\end{array}$ & $\begin{array}{l}\text { T-test: } \\
0.01\end{array}$ & $\begin{array}{l}\text { T-test: } \\
0.28\end{array}$ & $\begin{array}{l}\text { T-test: } \\
0.01\end{array}$ & $\begin{array}{l}\text { T-test: } \\
0.68\end{array}$ & $\begin{array}{l}\text { T-test: } \\
1.0\end{array}$ & $\begin{array}{l}\text { T-test: } \\
0.18\end{array}$ \\
\hline $\begin{array}{l}\text { Biolog } \\
\text { Chemi } \\
\text { Physic } \\
\text { Engine } \\
\text { Trigon } \\
\text { Health } \\
\text { Anator } \\
\text { Physio } \\
\text { Astron } \\
\text { Electro } \\
\text { Marin } \\
\text { Calcul } \\
\text { Geome } \\
\text { Draftir } \\
\text { techno } \\
\text { Progra } \\
\text { Web D } \\
\text { N=19 }\end{array}$ & $\begin{array}{l}\text { y } \\
\text { ing } \\
\text { netry } \\
\text { \& } \\
\text { gy } \\
\text { ny } \\
\text { ics } \\
\text { ystems } \\
\text { y } \\
\text { gy } \\
\text { ming } \\
\text { ign }\end{array}$ & $\begin{array}{l}\text { Chemis } \\
\text { Physics } \\
\text { Engine } \\
\text { Trigon } \\
\text { Astron } \\
\text { Electro } \\
\text { Calculy } \\
\text { Geome } \\
\text { Draftin } \\
\text { Progran } \\
\text { Web D } \\
\mathrm{N}=11\end{array}$ & $\begin{array}{l}\text { etry } \\
\text { y } \\
\text { s } \\
\text { echnology } \\
\text { ing } \\
\text { gn }\end{array}$ & $\begin{array}{l}\text { Chemis } \\
\text { Physics } \\
\text { Engine } \\
\text { Astron } \\
\text { Electro } \\
\text { Draftin } \\
\text { technol } \\
\text { Prograr } \\
\text { Web D } \\
\mathrm{N}=8\end{array}$ & $\begin{array}{l}\text { ing } \\
\text { ny } \\
\text { cs } \\
\text { gy } \\
\text { ming } \\
\text { ign }\end{array}$ & $\begin{array}{l}\text { Calcul } \\
\text { Geom } \\
\text { Trigon } \\
\mathrm{N}=3\end{array}$ & etry \\
\hline
\end{tabular}

When I looked at the total population of students across all class choices both in the pre and post visit surveys, I saw an increase in the total number of classes that students were interested in taking. Organic Chemistry and Astronomy showed the greatest increase, closely followed by Biology. The data shown in Figure 4.2 had a t-test result of 0.01 . The probability of the data being statistically significant was $99 \%$. Therefore the changes in class choices were statically significant from pre to post visit survey. I also did a t-test to determine the significance of life sciences apart from the rest of the courses. The result of 0.17 showed that life science courses were not responsible for the primary increase in 
student choices of science classes. Similarly, I broke out the math-specific courses and,33 with a score of 1 , also determined that these were not responsible for the overall increase in student interest in science classes.

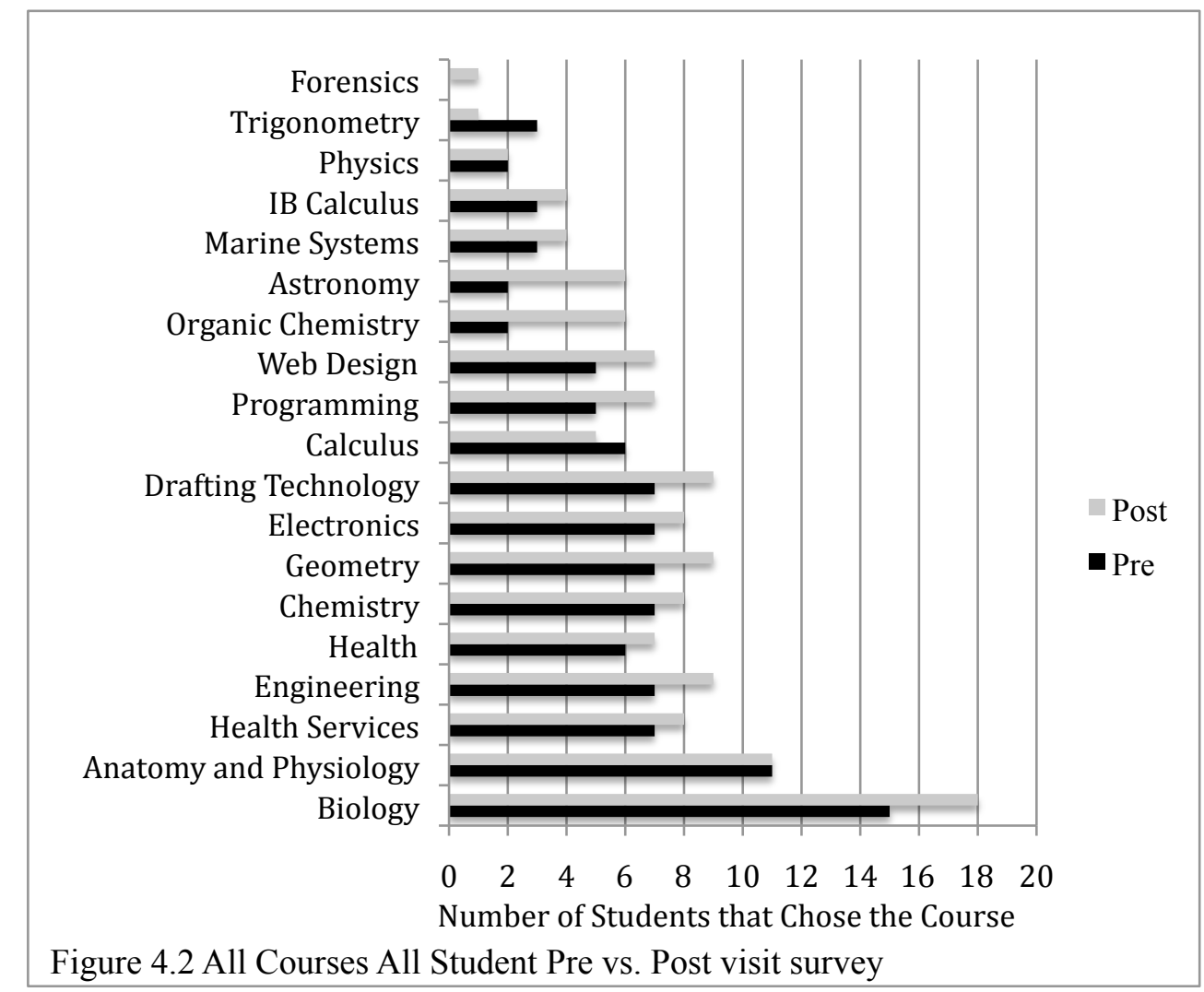

\section{Total student population group}

In creating this survey, I was particularly interested to see whether the role model visits would increase interest in non-life science courses. In fact, the greatest increase was in Organic Chemistry and Astronomy, suggesting that the visits may have had an impact supporting my hypothesis. All math-intensive courses showed positive increase in interest with a t-test result for this set of data was 0.01 . I want to emphasize that the increase came primarily from the category I am calling math-prerequisite science courses, which means that students were not choosing life sciences or math-specific classes. This means that the increase of class interest appeared in the same category of classes that the 
role model speakers represented. A few courses showed reduced interest. These

included Trigonometry and Calculus. Students erroneously chose these classes on their pre-visit survey, not knowing that they were ineligible to take these classes, based on their academic path.

Female only group

I broke out the answers of female students to determine how much increased interest in science classes this group showed. For this section the $\mathrm{n}$ is the number of classes being analyzed. While I did see an increase in the total number of classes that female students chose on the post-visit survey, the t-test results of 0.81 were not statistically significant for any of the four categories of courses. While the total population showed an increased interest in Math-Prerequisite Science Courses in support of my hypothesis, the female-only group showed an increased interest in Biology and Anatomy and Physiology in contrast to my hypothesis.

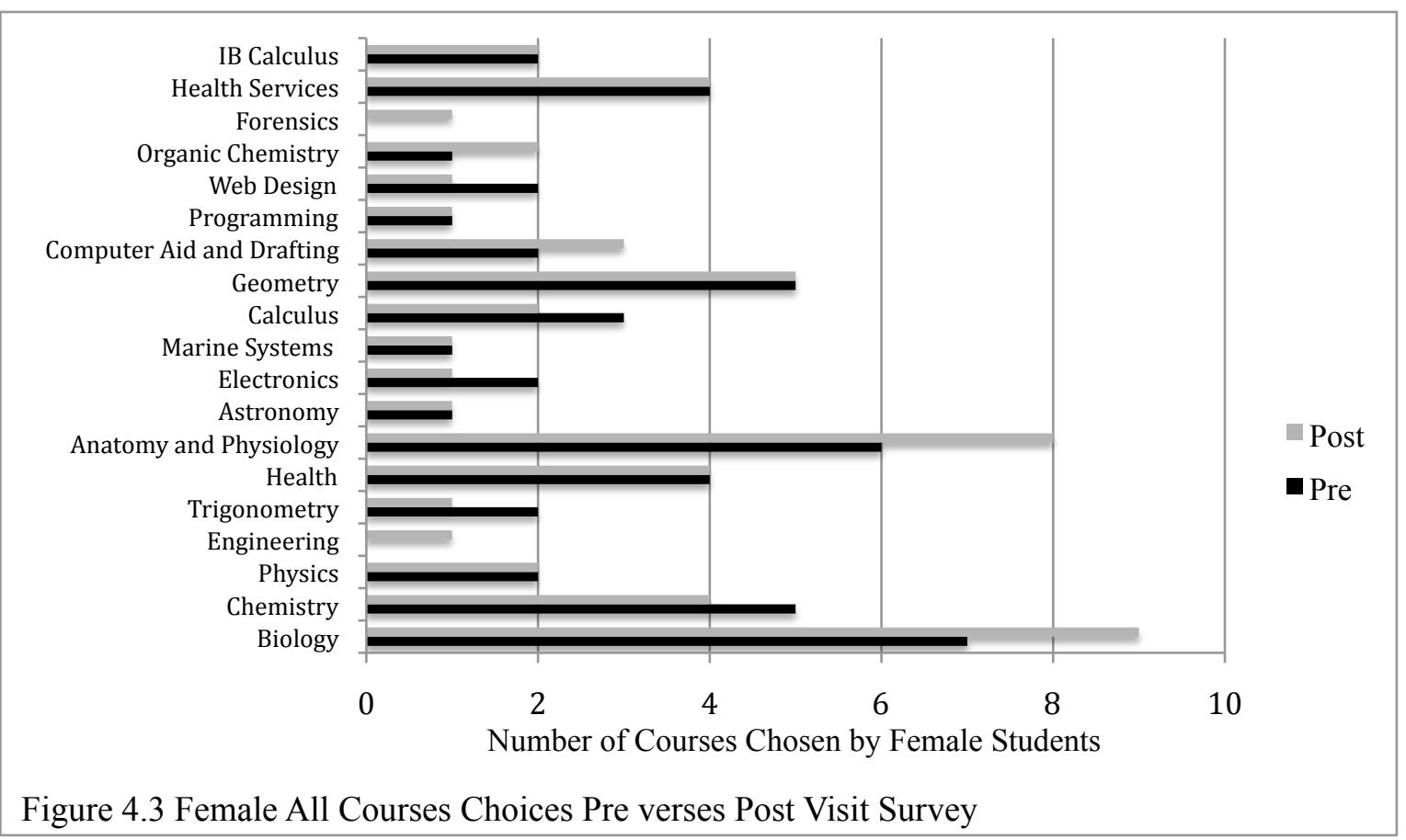


There was an evident decline in the types of classes female students wanted. For all classes except programming, astronomy, physics, and geometry, female students choose fewer of these classes. The only classes that showed an increase were drafting technology and engineering. The t-test result for this collection of results was 0.28 .

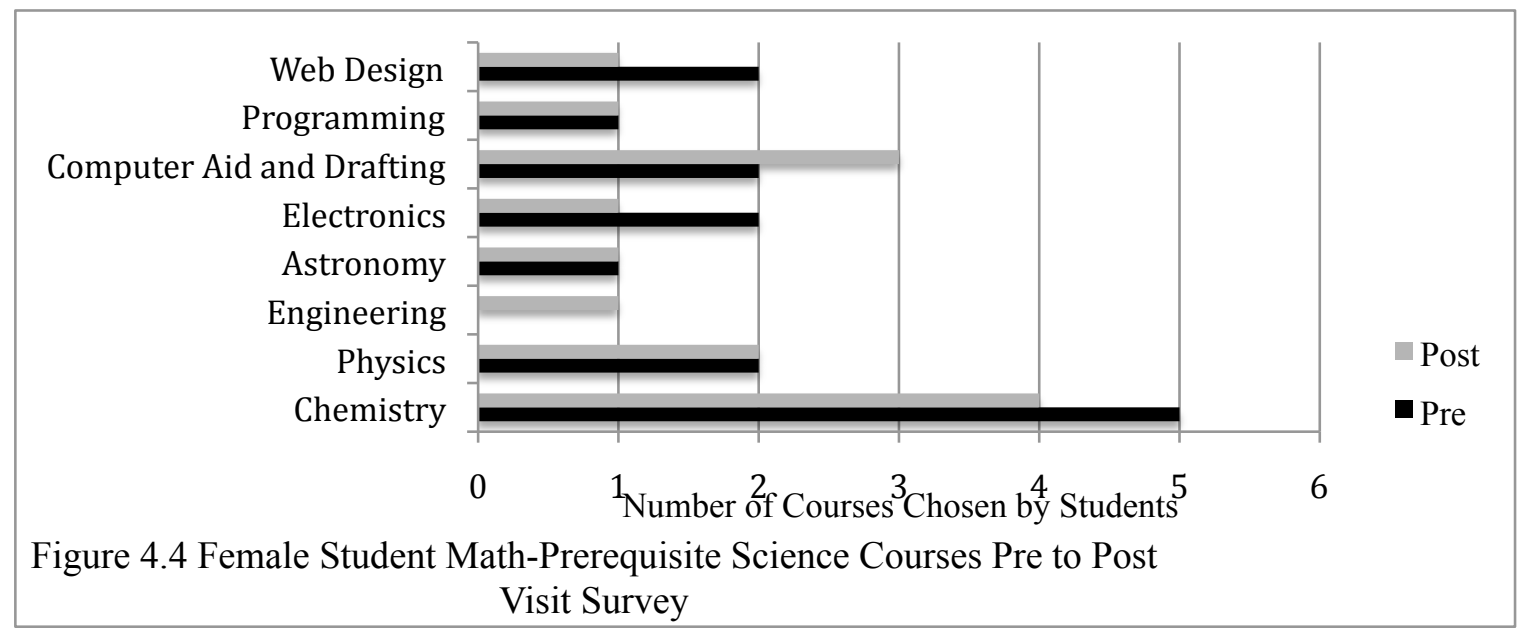

When I broke out the math-specific classes, I noticed that there was significant decline in female interest on the post-visit surveys. No female student added a math course in her post-visit survey. The t-test had a result of 0.18 , a result of no significance.

\section{Survey D: Specific Role Model Questions}

The Specific Role Model Questions asked three open-ended questions about student responses to the role model speakers. See Appendix F for complete list of student comments. In order to evaluate the results, I created four categories, including: factual information about the speaker or her job; factual information about self; advice given by 
the speaker; and revelations by students. Comments that were left blank or had the answer, "nothing," were left out of my analysis.

The largest number of comments, 64 out of a total of 107, fell into the "factual information about the speaker or her job" category. The entire list of student comments can be found in Appendix F. There are several themes within the answers students gave in this category. The first and most frequently written comment was related to the fact that speaker 3 had her first child at the age of 45 . Six female and two male students commented on this fact. Two female students and four males students commented that Speaker 2 had a career that did not require a college degree. Two female and four male students commented on Speaker 3's ability to work three jobs at the same time. Three male students commented that Speaker 2 gets to travel to a lot of different places as a part of her career.

The second category of comments related to "factual information about self." Overall, the comments in this section represented real thought on the part of students relating the speakers' careers to their own plans and aspirations. Fourteen out of one hundred and seven questions fell into this category. The third category consisted of "advice" that the students gathered from the speaker. There were 9 comments in this category. The final category was "revelations" that students had in relation to the speakers. There were 20 comments in this category. 
This study used four surveys to determine the impact of science role model visits on female students in my freshman integrated science classes. The larger question this study addresses is whether exposure to female role models in the sciences could have an impact on closing the gap between male and female entrance into STEM fields. My hypothesis was that exposure to female role models would result in an increased positive attitude toward the sciences as measured by the SAII Survey, a change in qualities they desired in a career as measured by the ROSE survey, and a greater interest in science classes as measured by the Class Choice Survey. Overall, the results of this study were inconclusive when it comes to the impact of role model visits on female students. In fact, in some cases, female students seemed actively deterred from the thought of pursuing sciences by the role model visits. However, there were other instances, particularly in the open-ended Specific Role Model Questionnaire, where it was clear that female students were surprised by the existence and success of the role models in ways that seemed to indicate new awareness of possibilities. What is clear is that students were impacted by the visits, which suggests that in fact, visits like this have the potential to be an important part of an effort to reduce the gender gap in STEM fields. The sample size, time constrains, and classroom culture likely contributed to the lack of statistical significance in this study, however, I believe the results still give us important information about the barriers to female entrance into STEM fields.

It is worth noting that male students showed the greatest impact. While I did not separate out male-only results in my surveys, it was clear from the results that male 
students were more affected by role model visits. This may be because male students

tend to have less self-doubt and are less limited by pre-conceptions of appropriate careers. (Nelson, 2001) It is also interesting that the male students were able to identify with female speakers who were speaking specifically about their experience as women in education and the workplace. The fact that female students were less able or willing to do this may reflect the greater barriers that females face in envisioning themselves succeeding in science. It may also be specific to the very small population of girls in this study.

The age of my student population may also have had an impact on their response to the role models. According to American Association of University Women in 2010 it has been shown that by the age of 12 or so students have "decided" whether they are good or bad at math and science and whether they like it. My study looked at trying to change the attitudes and choices of 14-15 year-old female students who have, according to this research, already formed a self-concept around math and science ability. Furthermore, these students were in the least advanced science classes offered at their school, which suggests that they came in with less math and science ability. They also may have less confidence about their ability to enter careers in science. In some ways, these are the students most in "need" of exposure to professional scientists. A more systematic study would repeat the role model exposure across different course levels in the same age group as well as potentially looking at a different age group.

The age group of my students tends to be characterized by a lack of maturity and respect toward unfamiliar adults. In my class this took the form of disrespect toward the speakers, including students who slept in class, walked out, and appeared disengaged. 
Adults who want to work with this age group need special skills in "hooking" and engaging the students. One of the speakers I brought had the class riveted, another speaker had difficulty in her first presentation, but was more successful in her second, and the third speaker did not come prepared with visuals, so students were not as engaged as they would have been. While it is not possible to draw conclusions from this study, it would be interesting to know whether the abilities of the speaker to engage students' impacts the responses students give on their surveys.

In the study by Gurer and Camp (2001), female students were exposed to role models in the form of classmates, teachers, and mentors that they met with on a regular basis. These were longer- term relationships. I was curious to know what impact bringing in a series of speakers might have even though this was a short-term contact. I wanted to see if this change in teaching methods would impact my students. Obviously, it is hard to measure the long-term impact of a single contact. Career choice is a complex and multidimensional process that cannot be traced to a single origin, but it is clear from the literature that a lack of role models has an inhibiting effect on female career choices. This is why I chose to use surveys that measure attitude and near-term interest in science classes.

The SAII measured what students perceived science to be and how they felt about it. I did not explicitly tell the students why I was having them do these surveys as my earlier experience in a work sample had suggested that when students knew I was looking for results, it skewed their answers. In addition, I did not ask the speakers to address the nature of science in any way. Instead, I had them focus on their science careers and their pathway into science as a female. This lack of explicit connection between the speakers' 
subjects and the questions on the survey may have resulted in the fact that I saw little 40 significant attitude change in this survey. This survey did not help answer my central question.

The ROSE survey measured the attributes of a career that student identified as desirable. Of the 26 statements on the survey, only 4 were specifically science related. I chose this survey because of its established reputation, but it turned out not to produce enough relevant data. However, 10 students showed significant pre- to post-visit changes. Eight of 10 of these were male students. I was using this survey to try to determine longterm changes in career choices, but I realized that all I can really measure is short-term responses.

The Class Choice List measured science classes that students were interested in taking. This is the only survey that I wrote and I found it produced the most significant data because it was tailored to my students and because of the way it let me distinguish between life science and math-prerequisite science courses. It let me know that the speakers effected male students and these students choose more science classes from preto post-visit survey. The results among female students were mixed, showing some gains in life science courses and little to no change in math-prerequisite science courses.

The unanswered question that emerges from this research is why female students tended to show results in opposition to my hypothesis - that is, results that indicated less interest in or greater anxiety about STEM fields. It may be that this study is not able to measure long-term results. If I were able to study these girls' actual college course choices and long-term career choices, would I see an impact? Given the nature of this study, it is difficult to say. It may also be that the kind of exposure represented by these 
visits was enough to alert female students to the fact that these careers are open to them, but also made them aware of how much work and commitment are required to succeed in traditionally male fields. At these students' age, projecting themselves into a long-term career path may be very difficult. It may be that female students need longterm mentoring by female role models as discussed in Taylor, et al (2001). Above all, though, I think that the results indicate the power of classroom culture and socio-cultural factors to shape female conceptions of their own life goals.

The fourth survey that I gave, the Specific Role Model Questionnaire, was unique among the surveys in that it consisted solely of the students' own words rather than asking them to choose from pre-determined options. This survey generated 107 comments from students and in some ways gave me the most insight into students' responses to the speakers. The fact that in the other three surveys female students showed results that went against my hypothesis was addressed or explained in the comments they wrote for this survey. Female students tended to express surprise or new awareness and sometimes fear related to the speakers' lives and careers. One student commented that the careers of the speakers seemed "complicated and messy," another commented that "it can be fun to dedicate your life to something you love and make money on," and still another, "that we can do what we love and be all you want to be." Six out of ten female students commented on the fact that one speaker was 45 when she became a mother. One student commented that she didn't see herself as "dorky scientist," implying that her perceptions of scientists were not changed by the speakers. There were three female students who commented that the speakers were doing jobs normally done by men. 
Male students were more likely to comment on the speakers' travel

opportunities and list descriptions of jobs they sounded interesting, while female students focused on personal attributes of the speakers. The comments of female students suggest that exposure to the speakers may have begun a paradigm shift in their thinking —a shift that is far from complete and may be accompanied by anxiety and even resistance toward careers that entail more effort and commitment from women. Knowing whether resistance is ultimately replaced by attraction would have to be part of a larger study. This study falls into the category of planting a seed that may take more time and mentoring to cultivate.

If I were going to repeat this study, I would bring 1 or 2 excellent speakers into my classes who had the time and energy to come back and interact with students and take students on trips to their workplace. I would still use my freshman science classes and would try to gather information about the students earlier in their education to see if they were more or less interested in science then. I would use the SAII, but within the context of an explicit discussion of the nature of science. I would use a survey similar to the ROSE but with questions customized to produce data related to science careers. I would also use the Class Choice list, but I might give more descriptions of classes. I might also talk specifically about the careers of the speakers and what the courses necessary to that career path are. I would do this study with several years' worth of students in order to aggregate data. I could also collect data on what science courses my students actually go on to take.

As a result of this study, I have learned that by bringing female scientists into my classroom I can benefit my students by providing them with exposure to new careers. 
Although all students may not decide to pursue a career in science as a result of this intervention, they may be inspired to investigate other potential career choices and aspirations. Bringing female scientists into the classroom is a method that classroom teachers can utilize that takes up very little class time and yields potentially beneficial results for all students. As a result of bringing female scientists into my classroom, it is my hope that all of my students will be more likely to explore careers in science. 
American Association of University Women (2010) Why so Few? Women in Science, Technology, Engineering, and Mathematics $\mathrm{http}: / /$ www.aauw.org/learn/research/whysofew.cfm

Burkam, David T., Valerie E. Lee and Becky A. Smerdon (1997) Gender and Science Learning Early in High School: Subject Matter and Laboratory Experiences. American Educational Research Journal, 34 (2).

Ceci, Stephen J.1; Williams, Wendy M.1; Barnett, Susan M. (2009) Women's Underrepresentation in Science: Sociocultural and Biological Considerations Psychological Bulletin, 135(2).

Eccles et. al., (1994) Understanding Women's Educational and Occupational Choices. Psychology of Women Quarterly, 18.

El-Sabban, Farouk (2008). Self-Expression Assignment as a Teaching Approach to Enhance the Interest of Kuwaiti Women in Biological Sciences. American Physiological Society, 32 (2).

Gurer, Denise and Tracy Camp. (2001) Investigating the Incredible Shrinking Pipeline for Women in Computer Science. National Science Foundation.

Maria Klawe and Nancy Leveson (1995) Women in Computing: Where are we now?

Communication of the ACM, January 38 (1).

Meyer, Karen (1998) Reflections on Being Female in School Science: Toward a Praxis of Teaching Science. Journal of Research in Science Teaching, 35 (4).

Moore, Richard W. and Rachel Leigh Hill Foy (1997) Scientific Attitude Inventory: A Revision (SAI II) Journal of Research in Science Teaching, 34(4).

NCES (2005) Table 142. Average science scale score of 12th-graders and percentage reporting various attitudes toward science, by selected student and school characteristics: 2005

http://nces.ed.gov/programs/digest/d09/tables/dt09_142.asp.

Nelson, Mary Ann and Stephen W. Smith. (2001) External Factors Affecting Gifted Girls' Academic and Career Achievements. Intervention in School \& Clinic, 37 (1).

Schreiner, Camilla \& Sjøberg, Svein (2004) Relevance of Science Education Questionnaire: Sowing the seeds of ROSE. Background, Rationale, Questionnaire Development and Data Collection for ROSE (The Relevance of Science 
Education) Dept. of Teacher Education and School Development, University of 45 Oslo.

Taylor, VS Vera Smoot Taylor, Katherine Woods Erwin, Manjushree Ghose, and Elena Perry-hornton (2001). "Models to increase enrollment of minority females in science-based careers." Journal of the National Medical Association, 93 (2). 
Appendix A: Survey A

\section{Questionnaire: SAI II}

There are some statements about science on the next two pages. Some statements are about the nature of science. Some are about how scientists work. Some of these statements describe how you might feel about science.

You may agree with some of the statements and you may disagree with others. That is exactly what you are asked to do. By doing this, you will show your attitudes toward science.

After you have carefully read a statement, decide whether or not you agree with it. If you agree, decide whether you agree mildly or strongly. If you disagree, decide whether you disagree mildly or strongly. You may decide that you are uncertain or cannot decide.

Then, find the number of that statement on the answer sheet, and CIRCLE the:
A if you agree strongly
B if you agree mildly
C if you are uncertain or cannot decide
D if you disagree mildly
E if you disagree strongly

Please respond to each statement and circle only ONE letter for each statement.

\section{Disagree}

\section{Strongly Agree}

Strongly

1. Good scientists are willing to change their ideas.

2. I would enjoy studying science.

3. I may not make great discoveries, but working in science would be fun.

4. Scientific work is useful only to scientists.

5. Scientific ideas may be changed over time.

6. Scientists are always interested in better explanation of things.

7. Most people are unable to understand science.

8. Working in a science laboratory would be fun.

9. Some questions cannot be answered by science.

10. When scientists have a good explanation, they do not try to make it better.

11. Scientists should not criticize each other's work.

12. Most people can understand science.

$\begin{array}{lllll}\text { A } & \text { B } & \text { C } & \text { D } & \text { E } \\ \text { A } & \text { B } & \text { C } & \text { D } & \text { E }\end{array}$

$\begin{array}{lllll}\mathbf{A} & \mathbf{B} & \mathbf{C} & \mathbf{D} & \mathbf{E}\end{array}$

13. Every citizen should understand science.

$\begin{array}{lllll}\text { A } & \text { B } & \text { C } & \text { D } & \text { E }\end{array}$

14. Scientific questions are answered by observing things. A

$\begin{array}{lllll}\text { A } & \text { B } & \text { C } & \text { D } & \text { E }\end{array}$

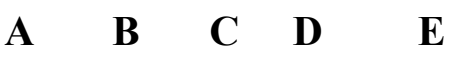

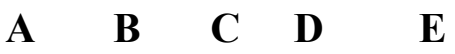

15. Anything we need to know can be found

$\begin{array}{lllll}\mathbf{A} & \mathbf{B} & \mathbf{C} & \mathbf{D} & \mathbf{E} \\ \mathbf{A} & \mathbf{B} & \mathbf{C} & \mathbf{D} & \mathbf{E} \\ \mathbf{A} & \mathbf{B} & \mathbf{C} & \mathbf{D} & \mathbf{E} \\ \mathbf{A} & \mathbf{B} & \mathbf{C} & \mathbf{D} & \mathbf{E}\end{array}$

out through science.

$\begin{array}{lllll}\mathbf{A} & \mathbf{B} & \mathbf{C} & \mathbf{D} & \mathbf{E}\end{array}$

$\begin{array}{lllll}\mathbf{A} & \mathbf{B} & \mathbf{C} & \mathbf{D} & \mathbf{E}\end{array}$

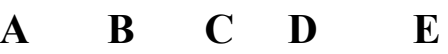

$\begin{array}{lllll}\text { A } & \text { B } & \text { C } & \text { D } & \mathbf{E}\end{array}$


16. A major purpose of science is to produce new drugs and save lives.

17. If one scientist says an idea is true, all other scientists will believe it.

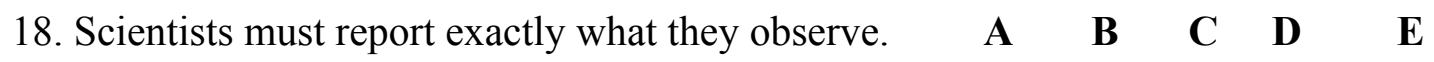
19. Scientists have to study too much.

20. I would like to be a scientist.

$\begin{array}{llllll}\text { A } & \text { B } & \text { C } & \text { D } & \text { E } & 47\end{array}$

21. The search for scientific knowledge would be boring. A

22. Only highly trained scientists can understand science. A

23. People must understand science because it affects their lives.

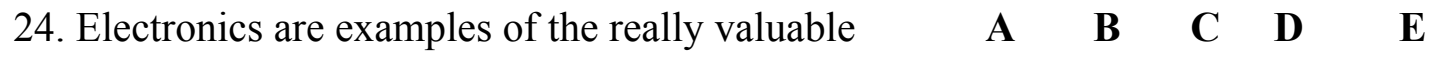
products of science.

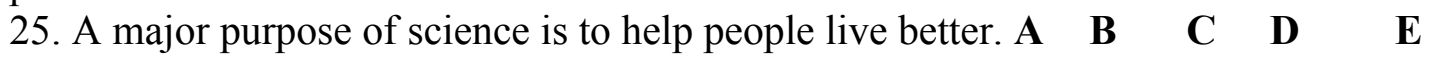

26. I would like to work with other scientists

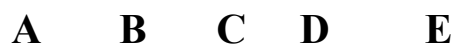
to solve scientific problems.

27. Scientists do not have enough time for their families or for fun.

28. Science tries to explain how things happen.

29. Scientific work would be too hard for me.

30. I do not want to be a scientist.

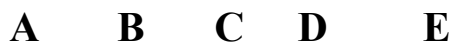

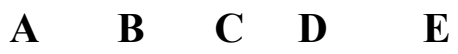

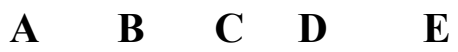

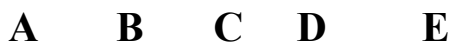


Appendix B: Survey B

\section{ROSE questionnaire}

\section{My future job}

How important are the following issues for your potential future occupation or job?

(Give your answer with a tick on each line. If you do not understand, leave the line blank.

1. Working with people rather than things

Very

Not

2. Helping other people

3. Working with animals

4. Working in the area of environmental protection

5. Working with something easy and simple

6. Building or repairing objects using my hands

7. Working with machines or tools

8. Working artistically and creatively in art

9. Using my talents and abilities

10. Making, designing or inventing something

11. Coming up with new ideas

12. Having lots of time for my friends

13. Making my own decisions

14. Working independently of other people

15. Working with something I find important and meaningful

important

important

16. Working with something that fits my attitudes and values

17. Having lots of time for my family

18. Working with something that involves a lot of travelling

19. Working at a place where something new happens frequently

20. Earning lots of money

21. Controlling other people

22. Becoming famous

23. Having lots of time for my interests, hobbies and activities

24. Becoming 'the boss' at my job

25. Developing or improving my knowledge and abilities

26. Working as part of a team with many people around me 
Appendix C: Survey C

\section{Class Choice List}

Name:

Gender:

Age:

1. Please mark the courses below that you have taken in high school with an $\mathrm{x}$.

2. Please mark the courses you would like to take in high school with an O.

$\begin{array}{ll}\text { Biology } & \text { Health } \\ \text { IB Biology } & \text { Anatomy and Physiology } \\ \text { Chemistry } & \text { Astronomy } \\ \text { IB Chemistry } & \text { Electronics } \\ \text { Physics } & \text { Forensics } \\ \text { IB Physics } & \text { Marine Systems } \\ \text { Engineering } & \text { Calculus } \\ \text { Trigonometry } & \text { Geometry }\end{array}$

Drafting technology

Programming

Web Design

Organic Chemistry

Integrated Science

Health Services

IB Calculus 
Appendix D: Survey D

\section{Specific Role Model Questions}

Name:

Gender:

- What was one thing you learned about the scientist's job?

- What was something that surprised you about the guest speaker?

- How did learning about this scientist impact you?

- What are the answers to the questions you wrote prior to the visit? 
Appendix E: Survey D Results

\section{$\underline{\text { All Student Comment Results }}$}

Factual Information About the Speaker

M: She was intelligent.

F: I learned that she works for major companies and tells them about flaws in their system.

F: She didn't go to college for the job she has now.

M: She gets to go to lots of places and business trips.

$\mathrm{M}$ : She has young teens.

M: Fix bridge or road

M: She loves her job.

F: She had her $1^{\text {st }}$ kid at 45.

F: She believes that there is living beyond earth.

M: That she is a mom and a scientist.

F: That she's a girl,

F: What she does and the roll she plays in her job.

M: She fixes a lot of other people's mistakes.

M: Her job didn't need college.

F: She helps roads and building be the best that they can be.

F: She looks for life on other planet.

F: I learned she was in her early 50's and had a kid at 45.

M: That she was pregnant at age of 45 .

F: That she is old and has a young kid.

M: That she work in so many jobs.

M: That she work at as a IT person and did services.

F: life on other planets, the space machines and all.

F: That she works with ODOT.

M: That they study geographic earthquakes.

F: Her career didn't require college.

F: She was a woman technician.

M: She hasn't found an alien.

M: She has 3 jobs.

M: She didn't know what she was going to do till college.

F: There might be aliens

F: She had a kid at 45

M: She knows a lot of stuff like alien and geo something.

M: That the earth is in the middle and other planets have water.

M: She has more than one job and looks for aliens.

F: She is in charge of data.

M: It's very complicated.

M: She travels a lot.

M: She worked.

M: That she was a very confident speaker. 
M: She had a kid at an older age.

$\mathrm{F}$ : She is smart.

M: She had a cool job.

M: She was tall.

M: Her job didn't need college.

M: Go aliens

M: They study plants.

M: She's over 50.

M: She didn't have to finish college.

M: She didn't have to finish college.

M: Her salary was 100,000 dollars every year.

M: It's very busy.

M: I learned that she is a computer scientist and she buys stuff and sells it for a high price.

M: She got to go to a lot of places.

M: She started at a young age.

F: She has three different hats, and she looks for life based on atmosphere gases.

F: She has three jobs.

M: She told us that the earth is in the middle. Other planets may have life.

M: She has more than one job.

M: She is a professor at PSU.

F: She looks for life on other planets.

F: I learned she is in her early 50's and had a kid at 45.

F: She looks for life on other planets.

F: Had a kid at 45.

F: I now know who an astrobiologist is.

Factual Information about Self

F: It helped me plan out when I will start searching for a job.

F: I learned something new.

M: I don't want to go to college even more.

M: Not very much, but it sure taught me a little bit.

M: That I like computer and there more than a bot.

F: It didn't really. I just found a few things interesting,

F: It helped me realize how difficult it is to have a scientific job.

F: Made me think about science.

M: I learned nothing. I already knowed everything she talked about.

M. Nothing impact me.

F: I know more about the earth.

M: Not very much so yeah.

F: I learned things I didn't know before.

$\mathrm{F}$ : It made me want to do more with science in my future.

Advice

M: You need to take math. 
F: That we can do what we love, and be all you want to be.

M: That being a research scientist is a really hard job.

M: That you really need to decide what you want for your career before making rash decisions.

F: That it can be fun to dedicate your life to something you love and make money on. $\mathrm{M}$ : A job can equal a lifesaver.

M: I learned that if it gets hard down the road don't give up.

F: To keep moving forward.

M: There are a lot of different kinds of scientists in the world.

Revelations

M: There is the kind of job like hers.

M: They earn 100 thousand a year.

M: That she does a lot jobs and she actually helps her boss when he made a mistake.

M: It's complicated being an engineer.

M: There are a lot of different kinds of scientists in the world.

M: Smart.

M: It is very busy work.

F: She majored in sociology and chose a different career path

$\mathrm{F}$ : It gave me more options.

F: That it's complicated and messy.

F: It made me see that women can be technicians too.

M: Not very much because it's pretty much construction.

M: She knows so much.

F: She wasn't a complete dorky scientist

M: It's fun.

M: She wasn't an atheist.

F: That she was short.

F: Normally it's men doing her job.

M: How hard it is to be an engineer.

M: Smart 


\section{SPe Portland State}

Human Subjects Research Review Committee

Post Office Box 751

Portland, Oregon 97207-0751
503-725-4288 tel

503-725-3416 fax

hsrrc@lists.pdx.edu

January 4,2011

To: Stephanie Van Raden

From: Mary Oschwald, HSRRC Chair P / ary

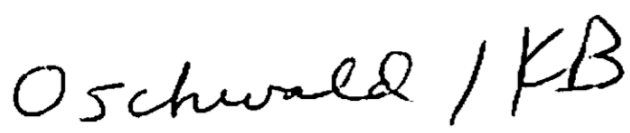

Re: HSRRC approval for your project titled, "The Effect of Role Models on the Attitudes and Career Choices of Female Students Enrolled in High School Science" (HSRRC Proposal \# 101596)

Dear Stephanie,

In accordance with your request, the Human Subjects Research Review Committee has reviewed your proposal referenced above for compliance with DHHS policies and regulations covering the protection of human subjects. The committee is satisfied that your provisions for protecting the rights and welfare of all subjects participating in the research are adequate, and your project is approved. Please not the following requirements:

Changes to Protocol: Any changes in the proposed study, whether to procedures, survey instruments, consent forms or cover letters, must be outlined and submitted to the Chair of the HSRRC immediately. The proposed changes cannot be implemented before they have been reviewed and approved by the Committee.

Continuing Review: This approval will expire on January 4,2012. It is the investigator's responsibility to ensure that a Continuing Review Report of the status of the project is submitted to the HSRRC two months before the expiration date, and that approval of the study is kept current.

The Continuing Review Report is available at www.rsp.pdx.edu/compliance_human.php and in the Office of Research \& Sponsored Projects (ORSP).

Adverse Reactions: If any adverse reactions occur as a result of this study, you are required to notify the Chair of the HSRRC immediately. If the problem is serious, approval may be withdrawn pending an investigation by the Committee.

Completion of Study: Please notify the Chair of the Human Subjects Research Review Committee (campus mail code ORSP) as soon as your research has been completed. Study records, including protocols and signed consent forms for each participant, must be kept by the investigator in a secure location for three years following completion of the study.

If you have questions or concerns, please contact the HSRRC in the Office of Research and Sponsored Projects (ORSP), 503-725-4288, Unitus Building, 6th Floor, 4th \& Lịncoln Streets. 